УДК 616.24+616.992:616-002.5

DOI: 10.26435/UC.V0I4(33).215

\title{
Е.В. Корж${ }^{1}$, Н.А. Подчос ${ }^{2}$ А.Ф. Завгородний ${ }^{2}$, Н.В. Клепак², Е.В. Янн ${ }^{2}$
}

${ }^{1}$ ГОО ВПО «Донецкий национальный медицинский университет имени М. Горького», Донецк

²Республиканская клиническая туберкулезная больница, Донецк

\section{МИКОБАКТЕРИОЗЫ ЛЕГКИХ У БОЛЬНЫХ ТУБЕРКУЛЕЗОМ}

В настоящее время проблема заболеваний легких, вызванных нетуберкулезными микобактериями (НТМБ), становится все более актуальной и широко обсуждается медицинскими специалистами во всех регионах мира. Сообщается о заметном росте заболеваемости микобактериозами, отмечается сложность их диагностики и лечения, отсутствие регламентированных протоколов и медицинских подразделений для оказания помощи данной категории пациентов $[1,2]$. НТМБ представляют собой сапрофитные условно патогенные микобактерии, широко распространенные в окружающей среде, из предложенных классификаций наибольшее распространение получила классификация Runyon, 1954, согласно которой их разделяют на 4 группы в зависимости от сроков роста и образования пигмента [3, 4]. Считается, что НТМБ не могут передаваться от больного человека к здоровому, заболевание возникает при снижении общего и/или местного иммунитета, массивном инфицировании большим количеством возбудителя [5, 6]. К микобактериозам склонны лица, страдающие хроническими заболеваниями бронхолегочной системы, из которых наибольшее значение имеют бронхоэктатическая болезнь, бронхиальная астма и хронический бронхит, муковисцидоз, пневмокониоз, туберкулез легких $[2,7,8]$. Очевидно, что такая предрасположенность реализуется через нарушение морфофункциональной целостности органов бронхолегочной системы и угнетение локальных защитных систем. В последние годы в связи с неуклонным ростом удельного веса населения, инфицированного вирусом иммунодефицита человека (ВИЧ), изучение особенностей развития, диагностики и лечения микобактериозов стало проводиться более активно [9, 10]. Показано, что заболеваемость микобактериозами резко возрастает при снижении количества PD4лимфоцитов ниже 50 кл/мкл, поэтому развитие легочного процесса, вызванного НТМБ, отражает крайне глубокое угнетение иммунитета.

Считается, что наиболее частыми возбудите- лями микобактериозов легких являются медленнорастущие виды - M. avium, M. intracellulare, M. gordonae, M. xenopi, M. каnsasii [4, 9]. Ввиду схожести морфофункциональных и клинических признаков патологии, вызываемой М. Avium и M. Intracellulare, их предлагают объединять в так называемый MAC-комплекс. МАС-комплекс является одним из главных этиологических факторов поражения легких у ВИЧ-инфицированных лиц с тяжелым угнетением иммунной системы $[3,11]$. Иногда к указанным микобактериям предлагается добавлять M. Scrofulaceum, объединяя их в единый комплекс MAIS, содержащий три основных патогенных для человека вида НТМБ. Диагноз микобактериоза считается установленным при высевании НТМБ не менее двух раз из разных проб мокроты или однократно из стерильного в норме материала (кровь, ликвор, образец ткани) [2, 5, 12].

В отдельную группу риска заболеваемости микобактериозами выделены больные туберкулезом легких, однако в литературных источниках не всегда приводятся критерии, на основании которых была идентифицирована туберкулезная этиология легочного процесса [7, 8]. Можно сделать вывод, что в случае выделения культуры НТМБ от пациента с клиникорентгенологическими признаками легочной патологиидифференциальнаядиагностикас туберкулезом легких является весьма затруднительной, и вынесение диагноза туберкулеза нередко базируется на клинико-рентгенологической картине заболевания и положительных результатах микроскопии мазка мокроты. Не вызывает сомнение и сложность дифференциальной диагностики туберкулеза и микобактериоза у ВИЧинфицированных лиц, на сегодняшний день выделены клинико-морфологические, рентгенологические, лабораторные критерии, позволяющие различить указанные заболевания, одна-

(c) Е.В. Корж, Н.А. Подчос, А.Ф. Завгородний, Н.В. Клепак, Е.В. Янн, 2019

(c) Университетская Клиника, 2019 
ко данный вопрос нуждается в дальнейшем изучении [12].

Целью исследования было выявить особенности бактериологической и рентгенологической картины микобактериозов легких у больных туберкулезом и оценить эффективность их лечения.

\section{МАТЕРИАЛ И МЕТОДЫ}

Был проведен анализ медицинских карт 26 стационарных больных туберкулезом легких, находившихся на лечении в Республиканской клинической туберкулезной больнице (РКТБ) г. Донецка в период 2015-2018 гг., у которых из мокроты были выделены НТМБ. С учетом существенного влияния иммунитета на развитие и течение микобактериозов больные были разделены на группы в зависимости от ВИЧстатуса: 15 больных, не инфицированных ВИЧ (1-я группа) и 11 ВИЧ-инфицированных пациентов (2-я группа). Изучали особенности анамнеза и рентгенологической картины патологии в легких, у 9 ВИЧ-инфицированных в Республиканском центре СПИДа лиц определяли содержание в крови PD4-лимфоцитов. Исследование мокроты проводили в бактериологической лаборатории РКТБ. Для культивирования микобактерий использовали твердую питательную среду Левенштейна-Йенсена и жидкую модифицированную среду Миддлбрук на аппарате BAPTEP MGIT 960. Принадлежность культуры к роду микобактерий определяли микроскопическим методом с окраской препаратов по ЦильНильсену. При наличии кислотоустойчивых бактерий (КУБ) выполняли иммунохроматографический тест (ИХТ) с определением антигена комплекса Mycobacterium tuberculosis: положительный результат свидетельствовал о принадлежности возбудителя к туберкулезным микобактериям, отрицательный - к атипичным. Также дифференциацию МБТ и НТМБ осуществляли путем посева полученной культуры на среду с добавлением салицилового натрия. Одновременно проводили культивирование полученного возбудителя на кровяном агаре для выявления присутствия неспецифической микрофлоры. Видовую идентификацию НТМБ осуществляли путем оценки морфологических и бактериологических характеристик выделенного возбудителя: образование или отсутствие пигмента, влияние света на пигментообразование, скорость и температурный режим роста колоний [11]. Тест на лекарственную чувствительность (ТЛЧ) атипичных микобактерий к противотуберкулезным препаратам проводили методом абсолютных концентраций на плотной питательной среде Левенштейна-Йенсена с использова- нием критических концентраций, установленных для M. tuberculosis. Тестировали препараты 1-го (изониазид (H), рифампицин (R), этамбутол (E), стрептомицин (S)) и 2-го ряда (аминогликозиды (Ag) - канамицин (Km) и амикацин (Am), капреомицин (Pm), фторхинолоны (Q) - офлоксацин/левофлоксацин (Ofx/Lfx) и моксифлоксацин (Mfx), а также циклосерин (Ps) и парааминосалициловую кислоту (PAS). Эффективность стационарного этапа лечения оценивали по удельному весу больных, выписанных из отделения в удовлетворительном состоянии для продолжения лечения в амбулаторных условиях.

Данные о возрасте больных, количестве CD4лимфоцитов в крови и продолжительности лечения в стационаре представляли в виде медианы, при определении различий между группами использовали критерий Вилкоксона-МаннаУитни, различия по частоте встречаемости изучаемого признака изучали с помощью точного метода Фишера [13].

\section{РЕЗУЛЬТАТЫ И ОБСУЖДЕНИЕ}

В 1-й и 2-й группах преобладали лица мужского пола (10 и 7 человек), ВИЧ-негативные пациенты были достоверно старше: медианы возраста составляли 51,9 лет и 40,0 лет соответственно, $p=0,043$. У 8 ВИЧ-инфицированных больных содержание PD4 в крови не превышало 98 кл/мкл, и только у одного больного достигало 413 кл/мкл, однако исследование выполняли за 6 месяцев до поступления в отделение. Медиана количества PD4 составляла 34 кл/мкл. Таким образом, подавляющее большинство ВИЧинфицированных пациентов имели глубокое угнетение иммунитета.

В 1-й группе сопутствующие заболевания выявляли у 10 человек из 15, чаще всего диагностировали ХОЗЛ (4 случая), остальные пациенты страдали заболеваниями, не поражающими дыхательную систему. В группе ВИЧинфицированных больных у 9 лиц из 11 выявляли патологию, ассоциированную с ВИЧ/СПИДом: кандидоз полости рта (4 случая), пневмоцистную пневмонию (3 случая), ВИЧ-энцефалопатию (2 случая), а также церебральный токсоплазмоз, Herpes Zoster, цитомегаловирусный ретинит (по одному случаю).

При поступлении в отделение 13 пациентам 1-й группы выставляли диагноз инфильтративного туберкулеза легких, рентгенологически у них наряду с инфильтратами в окружающей легочной ткани и/или соседнем легком определялись множественные полиморфные очаговые тени, у двух пациентов рентгенологические изменения были характерны для фибрознокавернозного туберкулеза. Лимфатические узлы 
в грудной полости увеличивались у одного больного. Обращало на себя внимание частое развитие деструкций - у 13 человек из 15 , при этом у 5 - множественных. Во 2-й группе у 7 больных диагностировали диссеминированный туберкулез легких, в том числе у 4 лиц на рентгенограммах наряду с диссеминацией определялись участки инфильтрации сливного характера. Внутригрудные лимфоузлы поражались у 6 человек. По сравнению с ВИЧ-негативными больными деструкции в легких у ВИЧ-инфицированных лиц встречались достоверно реже - у 3 из 11, p $=0,01$.

В группе ВИЧ-негативных больных 9 человек лечились от туберкулеза впервые, 3 человека получали повторное лечение и еще трое - химиотерапию мультирезистентного туберкулеза (МРТБ). Среди ВИЧ-инфицированных пациентов впервые лечились от туберкулеза 10 человек, и у одного пациента диагностировали рецидив туберкулеза (РТБ).

По результатам бактериологического исследования мокроты существенных различий по частоте выявления КУБ в мазках мокроты и роста возбудителя на питательных средах выявлено не было, примерно у трети пациентов обеих групп НТМБ из биологического материала выделяли неоднократно (см. табл.).

Анализ результатов идентификации НТМБ показал, что из мокроты ВИЧ-негативных пациентов ни разу не выделяли микобактерий 2-й группы атипии, частота роста представителей других групп была одинаковой (по 5 случаев). У ВИЧ-инфицированных лиц в подавляющем большинстве случаев вырастали НТМБ 3 группы, основным представителем которой является МАС-комплекс, что совпадает с данными литературы $[5,8,10]$. Несмотря на различный видовой состав НТМБ спектр их лекарственной чувствительности между группами практически не различался. Из противотуберкулезных препаратов 1 ряда часто выявляли устойчивость к $\mathrm{H}$, резистентность к нему была более распространенной среди ВИЧ-негативных больных. У большинства больных 1-й и 2-й групп сохранялась чувствительность к R, устойчивость к E выявляли чаще среди ВИЧ-негативных пациентов. B обеих группах отмечали высокие показатели резистентности к аминогликозидам, а также к $\mathrm{Cm}$. Относительно редко НТМБ проявляли устойчивость к фторхинолонам, независимо от ВИЧстатуса во всех случаях тестирования Mfх чувствительность к нему была сохранена. Наименее распространенной была резистентность к Cs.

Монорезистентность встречалась редко - по одному случаю среди больных 1-й (PAS) и 2-й (H) групп. Как правило, возбудитель был устойчив к сочетанию препаратов, из которых наиболее неблагоприятный вариант представляли случаи широкой устойчивости HREAgQPAS, которая примерно одинаково была распространена в обеих группах пациентов, при этом с особым постоянством встречались сочетания, включающие устойчивость к инъекционным препаратам 2 ряда (Ag и $\mathrm{Cm})$.

В обеих группах пациентов культуры МБТ из мокроты и бронхолегочных смывов высевались редко, что ставит вопрос о методах верификации у них туберкулеза. Среди больных, не инфицированных ВИЧ, рост МБТ был зафиксирован у 5 человек из 15, из них у двух пациентов неоднократно. Диагноз туберкулеза у этих больных не вызывал сомнения: в трех случаях диагностирован МРТБ, один больной получал повторное лечение в связи с рецидивом и один пациент лечился впервые. У двух больных (с МРТБ и РТБ) из мокроты дважды высевали НТМБ, что позволяет говорить о сочетании обеих инфекций. Среди ВИЧ-инфицированных пациентов рост МБТ наблюдали только у одного больного, получавшего лечение по поводу второго РТБ, и в одном случае наличие активного туберкулеза было подтверждено на вскрытии. Несмотря на отсутствие бактериологического подтверждения, с учетом анамнеза, клинико-лабораторной картины и результатов лучевого обследования всем пациентам был установлен диагноз туберкулеза легких. Микобактериоз был вынесен как сопутствующий диагноз у 6 больных 1-й группы, и как основной (в сочетании с туберкулезом) - у 9 больных 2-й группы.

Таким образом, если исключить случаи с бактериологически верифицированным диагнозом туберкулеза, то говорить о наличии изолированного атипичного микобактериоза легких (без сопутствующего туберкулеза) можно было в отношении трех пациентов 1-й группы, у которых при отсутствии роста культуры МБТ неоднократно (2 и более раза) высевались НТМБ 4-й группы атипии (быстрорастущие, представитель - M. Fortuitum) и которые имели сопутствующие хронические заболевания бронхолегочной системы (в двух случаях - бронхоэктатическую болезнь, и в одном - бронхиальную астму). Рентгенологически процесс у данных лиц характеризовался наличием массивной инфильтрации преимущественно в правом легком с множественными фокусными и очаговыми тенями в противоположном легком, полостями распада от мелких до 2-2,5 см в диаметре. Изменения в легких плохо поддавались лечению, на контрольных рентгенограммах через 60 дней отмечалось незначительная положительная динамика частичного рассасывания инфильтрации с сохранени- 
Результаты бактериологического исследования мокроты (бронхолегочных смывов)

Таблица.

\begin{tabular}{|c|c|c|}
\hline \multirow{2}{*}{ Показатели } & 1-я группа, n = 15 & 2-я группа, $\mathrm{n}=11$ \\
\hline & Случаи & Случаи \\
\hline КУБ в мазке & 7 & 6 \\
\hline $\begin{array}{l}\text { Высевание НТМБ: один раз } \\
\text { более одного раза }\end{array}$ & $\begin{array}{c}10 \\
5\end{array}$ & $\begin{array}{l}7 \\
4 \\
\end{array}$ \\
\hline 1 группа атипии & 5 & 2 \\
\hline 2 группа атипии & 0 & 1 \\
\hline 3 группа атипии & 5 & 8 \\
\hline 4 группа атипии & 5 & 0 \\
\hline Выполнено ТЛЧ & 13 & 10 \\
\hline Устойчивость (моно- и в сочетании) & 13 & 8 \\
\hline В том числе к: Н & 12 & 5 \\
\hline $\mathrm{R}$ & 5 & 2 \\
\hline E & 9 & 4 \\
\hline$S$ & 11 & 6 \\
\hline $\mathrm{Km} / \mathrm{Am}$ & 10 & 6 \\
\hline $\mathrm{Cm}$ & 6 & 6 \\
\hline Ofx/Lfx & 2 & 3 \\
\hline Cs & 2 & 1 \\
\hline PAS & 9 & 6 \\
\hline $\begin{array}{l}\text { Устойчивость к сочетаниям препаратов: } \\
\text { В том числе: }\end{array}$ & 12 & 7 \\
\hline HRES & 2 & 0 \\
\hline HRAgPAS & 2 & 0 \\
\hline HREAgCmQPAS & 2 & 2 \\
\hline HEAgCmPAS & 2 & 2 \\
\hline $\mathrm{HAgCm}$ & 4 & 1 \\
\hline AgCmPAS & 0 & 1 \\
\hline EAg & 0 & 1 \\
\hline
\end{tabular}

ем прежних размеров и количества деструкций. У остальных пациентов этиология процесса в легких требовала окончательной верификации, в том числе, бактериологической.

В группе ВИЧ-инфицированных больных положение осложнялось наличием глубокой иммуносупрессии и высокой вероятностью развития сочетанной патологии, в том числе дру- гих оппортунистических инфекций (пневмоцистоза, токсоплазмоза, цитомегаловирусного поражения, микозов). Повторный рост НТМБ при отсутствии роста культуры МБТ был зафиксирован у 4 пациентов (в трех случаях - 3-я группа атипии и в одном - 1-я группа). Содержание CD4 у данных лиц колебалось от 8 до 34 кл/мкл, у трех человек на рентгенограммах ОГК опреде- 
лялась диссеминация и внутригрудная лимфаденопатия, и у одной пациентки - массивный инфильтрат в нижней доле. С учетом полученных результатов категорически исключить наличие туберкулеза не предоставлялось возможным, поэтому диагностировали сочетание обоих инфекций.

При выборе схем химиотерапии легочного процесса результаты ТЛЧ выделенного возбудителя учитывали у 7 человек 1 -й группы, и у всех пациентов 2-й группы. Продолжительность лечения составляла соответственно 36-342 койко/ дней (медиана - 105), и 88-268 койко/дней (медиана - 138), статистически значимых различий между группами не было, $\mathrm{p}=0,264$. В группе пациентов, не инфицированных ВИЧ, лечение в режиме HRZE получали 6 человек, схема химиотерапии остальных больных включала от 5 до 6 противотуберкулезных препаратов 1-го и 2-го ряда, в том числе сочетание $\mathrm{Q}+\mathrm{Ag}$. Азитромицин, как средство для лечения непосредственно микобактериоза, назначали только двум лицам. Среди ВИЧ-инфицированных больных препараты HRZE принимали трое пациентов, и семеро больных получали лечение, включающее сочетание $\mathrm{Q}+\mathrm{Ag}$ с макролидами, то есть в данной группе НТМБ рассматривались как более влиятельный этиологический фактор.

Оценка эффективности химиотерапии показала, что среди ВИЧ-негативных больных летальных исходов не было, выписаны из отделения для дальнейшего лечения в амбулаторных условиях 10 человек, двое пациентов самовольно покинули отделение. Еще двое больных на момент анализа результатов исследований продолжали лечение в отделении, у них прекратилось бактериовыделение, наблюдалась положительная рентгенологическая динамика процесса в легких. Один больной с МРТБ переведен на схему паллиативной терапии. В группе ВИЧинфицированных больных 9 человек были выписаны из отделения с положительным результатом, одна больная умерла, и одна больная еще находилась в отделении, была абациллирована по мазку и посеву, на контрольной рентгенограмме определялось частичное рассасывание инфильтрации. Таким образом, оценивать предварительные результаты стационарного этапа лечения как успешные можно было у 12 из 15 больных 1-й группы и у 10 из 11 пациентов 2-й группы.

\section{В Ы В 0 Д Ы}

1. Из 15 ВИЧ-негативных больных туберкулезом, из мокроты которых были высеяны НТМБ, у трех человек можно было исключить туберкулез на основании отсутствия роста МБТ, неоднократного высевания микобактерий 4-й группы атипии и наличия сопутствующих хронических заболеваний бронхолегочной системы. У ВИЧинфицированных больных ввиду глубокой иммуносупрессии и высокого риска развития сочетанной патологии категорически исключить туберкулез легких не предоставлялось возможным даже при выполнении условий, применимых к лицам без ВИЧ-инфекции.

2. Из 11 культур НТМБ, выделенных от ВИЧинфицированных лиц, в 8 случаях возбудитель принадлежал к 3-й группе атипии (MACкомплексу), случаев высевания микобактерий 4-й группы зарегистрировано не было. У трех ВИЧ-негативных больных с наиболее вероятным диагнозом микобактериоза выделяли быстрорастущие НТМБ 4-й группы.

3. Резистентность НТМБ к различным сочетаниям противотуберкулезных препаратов определялась у всех ВИЧ-негативных лиц и у 8 из 10 ВИЧ-инфицированных пациентов с выполненным ТЛЧ, различий по видам устойчивости между группами не было. Наиболее часто НТМБ сохраняли чувствительность к рифампицину, моксифлоксацину и циклосерину, что следует учитывать при составлении схем лечения пациентов с высокой вероятностью микобактериоза до получения результатов ТЛЧ.

\section{Е.В. Корж${ }^{1}$, Н.А. Подчос ${ }^{2}$, А.Ф. Завгородний ${ }^{2}$ Н.В. Клепак ${ }^{2}$, Е.В. Янн}

${ }^{1}$ ГОО ВПО «Донецкий национальный медицинский университет имени М. Горького», Донецк

${ }^{2}$ Республиканская клиническая туберкулезная больница, Донецк

\section{МИКОБАКТЕРИОЗЫ ЛЕГКИХ У БОЛЬНЫХ ТУБЕРКУЛЕЗОМ}

В настоящее время проблема микобактериозов становится все более актуальной и широко обсуждается во всех регионах мира.

Целью исследования было выявить особенности бактериологической и рентгенологической картины микобактериозов легких у больных туберкулезом и оценить эффективность их лечения.

Материал и методы. Анализировали медицинские карты 26 больных туберкулезом, у которых из мокроты были выделены нетуберкулезные микобактерии. 
Среди обследованных 15 лиц ВИЧ-негативными (1-я группа) и 11 - ВИЧ-инфицированными (2-я группа). Изучали результаты лучевого и бактериологического обследования, оценивали эффективность лечения.

Результаты и обсуждение. Из 15 ВИЧ-негативных больных у 13 диагностировали инфильтративный туберкулез легких, рентгенологически наряду с инфильтратами определялись множественные полиморфные очаговые тени, в 13 случаях - деструкции. У 8 из 9 иммунологически обследованных ВИЧинфицированных больных содержание CD4 не превышало 98 кл/мкл. У 7 ВИЧ-инфицированных больных в легких определялась диссеминация, у 6 - поражение внутригрудных лимфоузлов, деструкции возникали реже - у 3 человек из 11, $\mathrm{p}=0,01$. От ВИЧнегативных пациентов ни разу не выделяли микобактерий 2-й группы атипии, частота роста 1,3 и 4 групп составила по 5 случаев. Из мокроты 11 ВИЧинфицированных больных в 8 случаях высевали микобактерии 3-й группы атипии. Устойчивость нетуберкулезных микобактерий к различным сочетаниям препаратов диагностировали у всех ВИЧ-негативных лиц и у 8 из 10 ВИЧ-инфицированных пациентов с выполненным ТЛЧ. По два случая в обеих группах определяли расширенную резистентность к препаратам 1-го и 2-го ряда, и реже всего регистрировали устойчивость к циклосерину, фторхинолонам и рифампицину. Изолированный микобактериоз можно было диагностировать у 3 пациентов 1-й группы на основании отсутствии роста туберкулезных, но неоднократного высевания нетуберкулезных микобактерий. В группе ВИЧ-инфицированных лиц из-за высокого риска сочетанной патологии исключить туберкулез не предоставлялось возможным. Медиана продолжительности лечения составляла 105 дней и 138 дней, успешные результаты получены у 12 больных 1-й и 10 лиц 2-й группы.

\section{Выводы}

Из 15 ВИЧ-негативных больных туберкулез можно было исключить у трех, у этих пациентов неоднократно высевали медленнорастущие микобактерии 4-й группы атипии при отсутствии роста микобактерий туберкулеза. В группе из 11 ВИЧ-инфицированных пациентов у 8 лиц выявляли микобактерии 3-й группы атипии, ввиду глубокой иммуносупрессии и высокого риска сочетанной патологии исключить туберкулез не предоставлялось возможным. Устойчивость нетуберкулезных микобактерий к противотуберкулезным препаратам определялась у всех ВИЧнегативных и в 8 случаях из 10 определений у ВИЧинфицированных больных. Наиболее часто сохранялась чувствительность к рифампицину, моксифлоксацину и циклосерину.

Ключевые слова: микобактериоз, больные туберкулезом, ВИЧ-инфекция.

\section{E.V. Korzh', N.A. Podchos ${ }^{2}$, A.F. Zavgorodniy ${ }^{2}$, N.V. Klepak ${ }^{2}$, E.V. Yann ${ }^{2}$}

${ }^{1}$ SEI HPE «M. Gorky Donetsk National Medical University», Donetsk

${ }^{2}$ Republican Clinical Tuberculosis Hospital, Donetsk

\section{PULMONARY MYCOBACTERIOSIS IN TUBERCULOUS PATIENTS}

At present, the problem of mycobacteriosis is becoming more urgent and is widely discussed in all regions of the world. Purpose of the study was to reveal the peculiarities of the bacteriological and radiologic features of pulmonary mycobacteriosis in tuberculous patients and to evaluate the effectiveness of their treatment.

Material and methods. Medical cards of 26 patients with tuberculosis were analyzed, from which nontuberculous mycobacteria were isolated from sputum. Of these, 15 persons were not infected with HIV (group 1) and 11 were HIV-infected (group 2). We studied anamnesis, results of roentgenologic and bacteriological examination, evaluated the effectiveness of treatment. Statistical processing was carried out using the MedStat package.

Results and discussion. On admission 13 of HIV-negative patients were diagnosed with infiltrative pulmonary tuberculosis, roentgenologically infiltrates and polymorphic focal shadows were revealed, in 13 there were destructions. Among 9 immunologically diagnosed HIV-infected patients 8 had CD4 count less than 98 cell $/ \mathrm{mm} 3$, 7 had dissemination in the lungs and 6 - increased intrathoracic lymph nodes. Destructions occurred rarely - in $3, p=0.01$. The 2 nd group mycobacteria culture was never received from HIV-negative patients, there were 5 cases of 1, 3 and 4 groups. In HIV-infected patients mycobacteria of the 3rd group grew in 8 cases. Resistance of nontuberculous mycobacteria to different combina- tions of antituberculous drugs was detected in all HIVnegative and in 8 of 10 tests of HIV-positive persons. Less common resistance was recorded to cycloserine, quinolones and rifampicin. Isolated mycobacteriosis can be diagnosed in 3 of 15 HIV-negative patients on the basis of absence of mycobacteria tuberculosis growth, repeated growth of non-tuberculous mycobacteria. It was impossible to exclude tuberculosis in the HIV-infected patients because of high comorbidity risk. The median duration of the treatment was 105 days and 138 days, successful results were obtained in 12 patients of the 1 st and 10 patients of the 2nd group.

Conclusions

Tuberculosis could be excluded in 3 HIV-negative patients, non-tuberculosis mycobacteria of the 4th group were presented in all of these patients. Pathogen of 8 HIV-infected patients belonged to the 3-rd group. Due to the advanced immunosuppression and high risk of the combined pathology, it was not impossible to exclude tuberculosis. Resistance of non-tuberculosis mycobacteria to anti-tuberculosis drugs was determined practically in all individuals. Susceptibility of mycobacteria to rifampicin, moxifloxacin and cycloserine was most often revealed.

Key words: mycobacteriosis, tuberculous patients, HIV infection. 


\section{ЛИТЕРАТУРА}

1. Зимина В.Н., Дегтярева С.Ю., Белобородова Е.Н., Кулабухова Е.И., Русакова Л.И., Фесенко О.В. Микобактериозы: современное состояние проблемы. Клиническая микробиология и антимикробная химиотерапия. 2017; 19 (4): 276-282

2. Р. Флото, К. Оливье, Л. Сайман, Ч. Дейли, Жан-Луи Херрманн, Д. Ник, П. Нун, Д. Билтон, П. Коррис, Р. Гибсон, С. Хемпстед, К. Кетц, К. Сабадоса, И. Серме-Годелю, А. Смит, Якко ван Инген, Р. Уоллас, К. Уинтроп, Б. Маршалл, Ч. Хаворт. Согласованные рекомендации Американского фонда кистозного фиброза (муковисцидоза) и Европейского общества кистозного фиброза по лечению микобактериоза у пациентов с кистозным фиброзом. С-Пб.: Благотворительный фонд «Острова». 2017. 32. http://mukoviscidoz.org/doc/konsensus/2017/ mikobakterioz-redak-kashirskaj.pdf

3. O. Joseph Falkinham. Environmental sources of nontuberculous mycobacteria. Clin Chest Med. 2015; 36(1): 35-41. Doi: 10.1016/j.ccm.2014.10.003

4. A. Timpe, E.H Runyon. The relationship of «atypical» acidfast bacteria to human disease; a preliminary report. J Lab Clin Med. 1954; (2):202-209.

5. Гунтупова Л.Д., Борисов С.Е., Макарова М.В., Хачатурьянц Е.Н. Микобактериозы органов дыхания: эпидемиология, микробиологические и клинические аспекты диагностики. Эпидемиология и инфекционные болезни. 2012; (2): 8-14.

6. Бондаренко В.Н., Штанзе В.А., Гопоняко С.В., Золотухина Л.В. Клинико-рентгенологическая характеристика микобактериозов легких. Проблемы здоровья и экологии. 2017: 38-43.

7. Кузюта И.Л., Кривонос П.С. Особенности диагностики и клинико-рентгенологические проявления легочных микобактериозов. Медицина: вызовы сегодняшнего дня: материалы III международной научной конференции. Январь 2016. Москва; 2016: 34-39. URL https:// moluch.ru/conf/med/archive/193/9413/

8. Эргешов А.Е., Шмелев Е.И., Ковалевская М.Н., Карпина Н.Л., Ларионова Е.Е., Черноусова Л.Н. Микобактериозы в практике врачей пульмонологов и фтизиатров. Туберкулез и болезни легких. 2016; 94 (9): 39-43. DOI 10.21292/2075-1230-2016-94-9-39-43

9. Пантелеев А.М. Микобактериозы на фоне ВИЧинфекции. http://congress-ph.ru/common/htdocs/ upload/fm/cardiotorakal/prez/N20-02-3.pdf

10. Зимина В.Н., Альварес М.В. Фигероа, Дегтярева С.Ю., Белобородова Е.Н., Зюзя Ю.Р. Диагностика микобактериоза у больных ВИЧ-инфекцией. Инфекционные болезни. 2016; 14 (4): 63-70. DOI: 10.20953/1729-92252016-4-63-70

11. Лямин А.В., Жестков А.В., Исматуллин Д.Д., Ковалев А.М. Лабораторная диагностика микобактериозов. Вестник современной клинической медицины. 2017; 10 (1): 29-35. DOI: 10.20969/VSKM.2017.10(1).29-35

12. Пантелеев А.М., Никулина О.В., Христусев А.С., Драчева М.С., Соколова О.С., Зонова А.В. Дифференциальная диагностика туберкулеза и микобактериоза у больных ВИЧ-инфекцией. Туберкулёз и болезни лёгких. 2017; 95 (10): 47-52.

13. Лях Ю.Е., Гурьянов В.Г., Хоменко В.Н., Панченко О.А. Основы компьютерной биостатистики. Анализ информации в биологии, медицине и фармации статистическим пакетом MedStat. Донецк; 2006. 214.

\section{REFERENCES}

1. Zimina V.N., S.Ju. Degtjareva, Beloborodova E.N., Kulabuhova E.I., L.I Rusakova, Fesenko O.V. Mikobakteriozy: sovremennoe sostojanie problemy [Micobacteriosis: current state of a problem]. Klinicheskaja mikrobiologija i antimikrobnaja himioterapija. 2017; 19 (4): 276-282 (in Russian).

2. R. Floto, K. Oliv'e, L. Sajman, Ch. Dejli, Zhan-Lui Herrmann, D. Nik, P. Nun, D. Bilton, P. Korris, R. Gibson, S. Hempsted, K. Ketc, K. Sabadosa, I. Serme-Godelju, A. Smit, Jakko van Ingen, R. Uollas, K. Uintrop, B. Marshall, Ch. Havort. Soglasovannye rekomendacii Amerikanskogo fonda kistoznogo fibroza (mukoviscidoza) i Evropejskogo obshhestva kistoznogo fibroza po lecheniju mikobakterioza u pacientov s kistoznym fibrozom [The agreed recommendations of the American fund of cystous fibrosis (mucoviscidosis) and the European society of cystous fibrosis about treatment of a micobacteriosis in patients with cystous fibrosis]. S-Pb.: Blagotvoritel'nyj fond «Ostrova». 2017. 32. http://mukoviscidoz.org/doc/konsensus/2017/ mikobakterioz-redak-kashirskaj.pdf (in Russian).

3. O. Joseph Falkinham. Environmental sources of nontuberculous mycobacteria. Clin Chest Med. 2015; 36 (1): 35-41. Doi: 10.1016/j.ccm.2014.10.003

4. A. Timpe, E.H Runyon. The relationship of «atypical» acid-fast bacteria to human disease; a preliminary report. J Lab Clin Med. 1954; (2): 202-209.

5. Guntupova L.D., Borisov S.E., Makarova M.V., Hachatur E.N.'janc Mikobakteriozy organov dyhanija: jepidemiologija, mikrobiologicheskie i klinicheskie aspekty diagnostiki [Micobacteriosis of respiratory organs: epidemiology, microbiological and clinical aspects of diagnostics]. Jepidemiologija i infekcionnye bolezni. 2012; 2: 8-14 (in Russian)

6. Bondarenko V.N., Shtanze V.A., Goponjako C.V., Zolotuhina L.V. Kliniko-rentgenologicheskaja harakteristika mikobakteriozov legkih [Clinical and roentgenologic characteristic of pulmonary micobacteriosis]. Problemy zdorov'ja i jekologii. 2017: 38-43 (in Russian).

7. Kuzyuta I.L., Krivonos P.S. Osobennosti diagnostiki i kliniko-rentgenologicheskie proyavleniya legochnykh mikobakteriozov [Features of diagnosis and clinical and radiologic manifestations of pulmonary mycobacteriosis]. Meditsina: vyzovy segodnyashnego dnya: materialy III mzhdunarodnoi nauchnoi konferentsii. Yanvar' 2016. Moskva; 2016: 34-39. URL https://moluch.ru/conf/med/ archive/193/9413/ (in Russian).

8. Jergeshov A.E., Shmelev E.I., Kovalevskaja M.N., Karpina N.L., Larionova E.E., Chernousova L.N. Mikobakteriozy v praktike vrachej pul'monologov i ftiziatrov [Micobacteriosis in practice of pulmonologists and phthisiatricians]. Tuberkulez i bolezni legkih. 2016; 94 (9): 39-43. DOI 10.21292/2075-1230-2016-94-9-39-43 (in Russian).

9. Panteleev A.M. Mikobakteriozy na fone VICh-infekcii [Micobacteriosis on the background of HIV infection]. http://congress-ph.ru/common/htdocs/upload/fm/ cardiotorakal/prez/N20-02-3.pdf (in Russian).

10. Zimina V.N., Al'vares Figeroa M.V., Degtjareva S.Ju., Beloborodova E.N., Zjuzja Ju.R. Diagnostika mikobakterioza u bol'nyh VICh-infekciej [Diagnostics of micobacteriosis in patients with HIV infection]. Infekcionnye bolezni. 2016; 14 (4): 63-70. DOI: 10.20953/1729-92252016-4-63-70 (in Russian).

11. Ljamin A.V., Zhestkov A.V., Ismatullin D.D., Kovalev A.M. Laboratornaja diagnostika mikobakteriozov [Laboratory diagnostics of micobacteriosis]. Vestnik sovremennoj klinicheskoj mediciny. 2017; 10 (1): 29-35. DOI: 10.20969/VSKM.2017.10(1).29-35 (in Russian). 
12. Panteleev A.M., Nikulina O.V., Hristusev A.S., Dracheva M.S., Sokolova O.S., Zonova A.V. Differencial'naja diagnostika tuberkuleza i mikobakterioza u bol'nyh VICh-infekciej [Differential diagnosis of tuberculosis and a micobacteriosis in patients with HIV infection]. Tuberkuljoz i bolezni ljogkih. 2017; 95 (10): 4752 (in Russian).

13. Lyakh Yu.E., Gur'yanov V.G., Khomenko V.N., Panchenko O.A. Osnovy komp'yuternoi biostatistiki. Analiz informatsii v biologii, meditsine i farmatsii statisticheskim paketom MedStat [Fundamentals of computer biostatistics. The analysis of information in biology, medicine and pharmacy with statistical MedStat package]. Donetsk; 2006. 214 (in (in Russian). 